The Geographical Journal of Nepal

Vol. 15: 103-118, 2022

DOI: https://doi.org/10.3126/gjn.v15i01.42889

Central Department of Geography,

Tribhuvan University, Kathmandu, Nepal

\title{
Flood risk mapping and analysis: A case study of Andheri Khola catchment, Sindhuli district, Nepal
}

\author{
Buddhi Raj Shrestha, Liladhar Sapkota, Chhabi Lal Chidi*
}

Central Department of Geography, Tribhuvan University, Kathmandu

*Corresponding author: chidichhabilal@gmail.com

Received: 23 September, 2021; Accepted: 05 December, 2021; Published: March, 2022

\begin{abstract}
Nepal is one of the world's most vulnerable countries to a variety of risks, including severe floods. This could result in the loss of lives and property, the relocation of people, the damage of physical infrastructures, homes, and the disruption of people's socioeconomic functions and the country's economy in a variety of ways. River flooding is caused by heavy monsoon rainfall, weak geology, unplanned infrastructure construction along the embankments, and mining in upstream riverbeds. The Andheri Khola (river) is a tributary of the Sunkoshi River that frequently floods, affecting the inhabitants along the way. In Nepal, little effort has been made to comprehend the flood risk in tiny catchment regions such as Andheri Khola, despite the fact that this sort of small catchment is affecting Nepal's numerous new rising towns and urban areas in many ways. To analyse the one-dimensional flood plain, HEC-RAS, Ras Mapper, and ArcGIS were used. The WECS/DHM approach was used to estimate flood frequency in different return periods in order to determine the flood risk in the research area. The study finds that the floods of 2, 50,100, and 1000 years return periods cover a maximum of 35, 41.9, 42.7, and 49.72 hectare area, respectively. The majority of the flooded sites had water depths of more than 3 meters. More than $70 \%$ of the sandy area in the study region is prone to flooding. Furthermore, the cultivated areas are located in a low to moderate risk area.
\end{abstract}

Keywords: Flood, inundation, HEC-RAS, risk, vulnerability 


\section{Introduction}

Nepal is vulnerable to a variety of natural and human-caused disasters, and it is one of the multi-hazards disaster hotspot countries (Dilley, et al., 2005). Landslides, floods, snow avalanches, glacial lake outburst floods (GLOF), hailstorms, drought, fires, famine, and diseases, as well as an earthquake, have all occurred in Nepal (MoHA and DPNeT, 2013). Due to its weak geology, intense seismic activity, and high rainfall, Nepal is vulnerable to water-related calamities (DWIDP, 2013). Over the 45 years from 1971 to 2016, 4,160 floods were recorded in Nepal, generating flooding in all provinces and incurring human casualties and infrastructural damage (NSET, 2016; Shrestha et al., 2020).

Flood hazard, according to Brooks (2003), is the risk of damaging flood events of a specific scale occurring within a given period and territory. A model known as the Hydrologic Engineering Center's River Analysis System (HEL-RAS) was established by the United States Army Corps of Engineers (USACE). This model is commonly used to identify the flood plain and observe floods and flood-related dangers (Brunner 2016; Horritt and Bates, 2002; Liu et al., 2019; El-Naqa and Jaber, 2018; Huțanu et al., 2020). HEC-RAS was used to run the hydrodynamic model in Nepal's several basins (Banstola et al., 2019; Bhattarai et al., 2019; Dhital et al, 2005; Gautam and Kharbuja, 2006; Thapa et al., 2020).

The flood risk map of the Lakhandei River was prepared by Awal (2007) using the hydraulic model and GIS. Dangol (2014) used a constant flow model of HEC-RAS to create inundation maps of the Balkhu Khola. The flood risk in the Ratu Khola watershed was mapped and assessed using HEC-RAS (Khanal et al., 2007). On the southern slope of the Himalayas, Aryal et al. (2020) employed HEC-RAS to create a flood inundation map for flood hazard and vulnerability analysis. Karki et al. (2011) also looked into flood hazards, their effects, and community resilience at the watershed level. Tamang and Tamrakar (2017), for example, employed GIS and HEC-RAS to create flood risk maps for the Malekhu Khola in central Nepal.

As defined, flood risk assessment involves a thorough understanding of the flood's conditional components, and it aids planners in identifying high-risk areas and prioritizing mitigation and response operations (Awal, 2007). In Nepal, flooding, landslides, and soil erosion are all too common, especially during the monsoon season (Shrestha et al., 2004). Several academics have looked into flood disasters from a variety of angles, including flood forecasting, flood risk assessment, and flood mapping, all of which have aided in the development of effective disaster risk management techniques in Nepal 
(Dhungana et al., 2016; Mool et al., 2011). Flood studies and flood-related difficulties in small catchment regions, on the other hand, are scarce. Nepal is also more prone to flooding (Sharma et al., 2019). On the other hand, Nepalese people live with threats and accept them as a way of life.

Andheri Khola is a tributary of the Sunkoshi River, and it has been observed in the field that there occurs several floods every year, which affect the inhabitants. Despite the fact that minor catchment areas like Andheri Khola have an impact on Nepal's many newly emerging cities as well as older metropolitan areas in diverse ways, no serious attention has been paid to them in Nepal. Furthermore, Khurkot is one of the newly rising towns along Nepal's mid-hill highway corridor, one of the most important infrastructural projects suggested by the Nepalese government in the previous decade (Dahal and Timalsina, 2017). As a result, the primary goal of this research is to analyze the flood risk in the Andheri Khola basin, which includes the recently developed town of Khurkot. The one-dimensional hydraulic model HEC-RAS, QGIS, and RAS mapper were used to estimate the risk. This research can help the local authority to formulate land use policy and planning in a variety of ways, including ensuring the safety of people, physical infrastructure, and housing, as well as conserving the local environment and economy. This study aims to assess flood vulnerability and risk in a small catchment in Nepal's hills, in the context of newly expanding infrastructure facilities, market towns, and other developments, in order to avoid further expansion in risky areas and to develop market towns and land use zoning based on risk levels.

\section{Methods and materials}

\section{The study area}

The study area is the Andheri Khola watershed, which is one of the Sunkoshi River's tributaries in the Sindhuli district of Nepal's Bagmati province. This area is close to Khurkot, one of the mid-hill region's burgeoning new towns. The study region is situated $27^{\circ} 16^{\prime} 0.68^{\prime \prime} \mathrm{N}$ to $27^{\circ} 20^{\prime} 0.96^{\prime \prime} \mathrm{N}$ latitude and $85^{\circ} 56^{\prime} 0^{\prime \prime} \mathrm{E}$ to $86^{\circ} 36^{\prime} 10.50^{\prime \prime} \mathrm{E}$ longitude. The Mahabharat region in Kamalamai municipality is home to the upstream watershed of the Andheri Khola, which flows north to the Sunkoshi River. The model's upstream and downstream boundaries are located at Phedi Gaun and below the Andheri Khola Bridge, respectively. Figure 1 shows a map of the study area. 


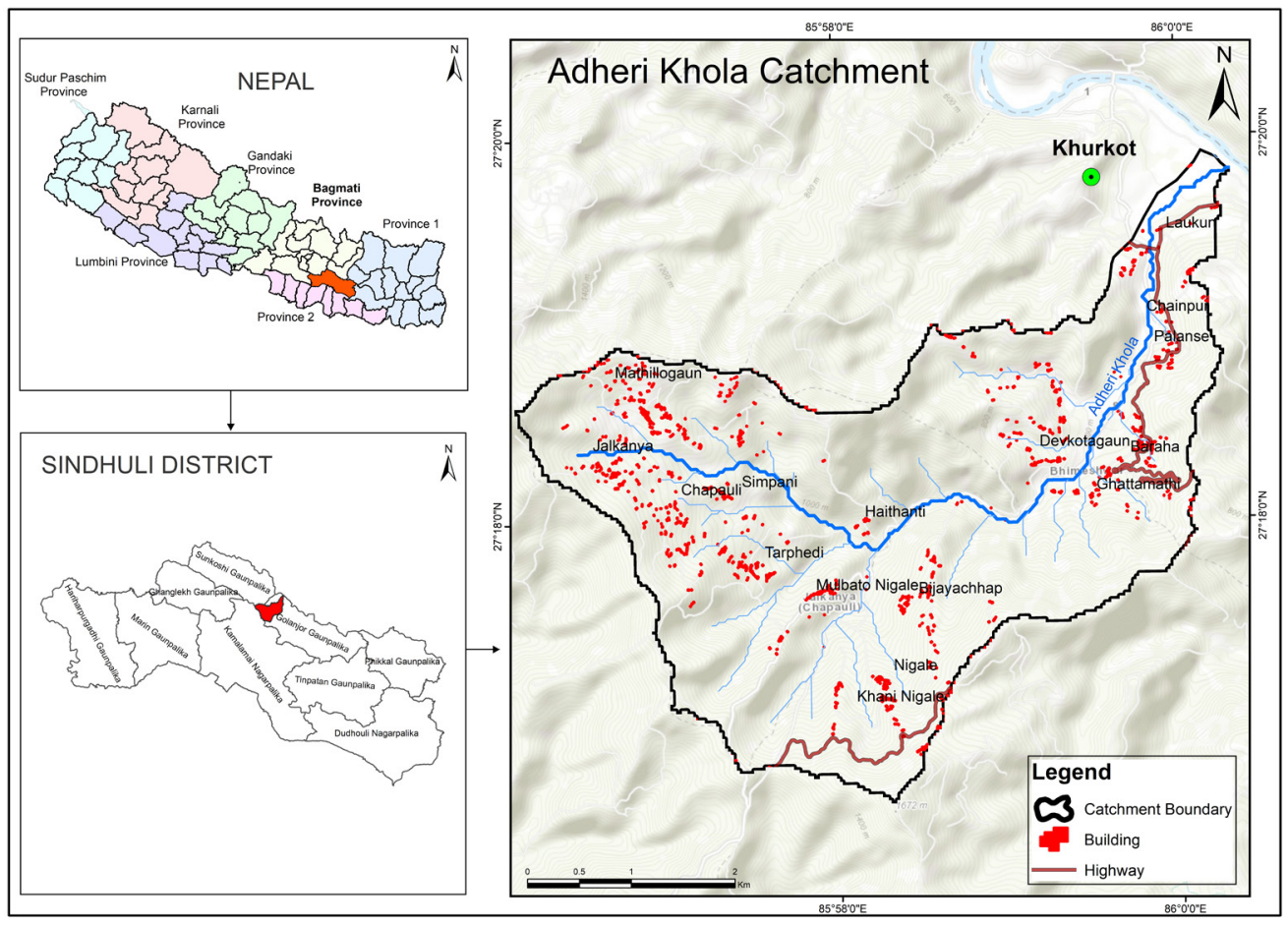

Figure 1: The study area: Andheri Khola watershed

\section{Data preparation and analysis}

Secondary data sources are used to assess flood hazard and risk in the Andheri khola catchment. The topographic surface was created using a Digital Elevation Model (DEM) with a spatial resolution of $30 \mathrm{~m}$, which can be found on the United States Geological Survey's (USGS) online portal (https://earthexplorer.usgs.gov). The open street map was used to calculate land usage, construction, and infrastructure for the year 2021. In RAS Mapper, the river network was obtained from DEM-generated landscape. The river geometry was created using 30-meter spatial resolution DEM (Aryal et al., 2020). At $25 \mathrm{~m}$ intervals, cross-sections were obtained. More cross-sections were constructed when needed to meet the needs of the river's meandering stretch. Flood frequency was computed for 2-year and 100-year floods using an equation established by the Water and Energy Commission Secretariat (WECS) and the Department of Hydrology and Meteorology (DHM), as well as a 1000-year return time. The digitization was carried out in the direction of the flow Figure 2. 


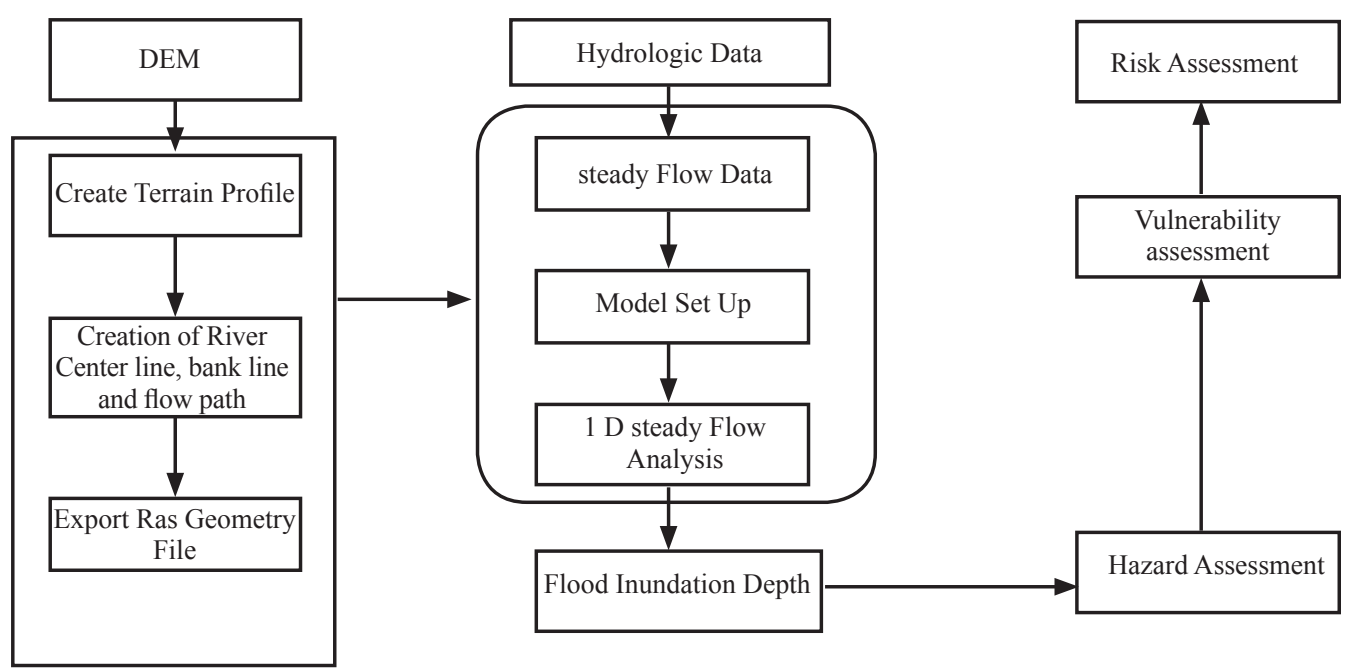

Figure 2: Methodology for flood hazard and risk assessment

Using a landscape Google Earth geo-referenced image, the river centerline was digitized. The river was given river and reach names after digitization, allowing it to be identified in HEC-RAS. Riverbanks were built in the same way as river centerlines were. Bank line digitization begins at the upstream end, with the left bank being digitized first before moving downstream. During the flood event, the flow path layer was a collection of lines that followed the center of the bulk of water moving down the river. To create profiles, elevation data for each terrain section was taken. Given the direction of the river, which does not connect, the cut lines were drawn perpendicular and directional from the left bank to the right bank. To build a geometry file, the final step was to create a RAS import file in HEC-RAS.

A Cross-section point filter was used to remove duplicate cross-section points from the same section (over 500). For HEC-RAS processing according to land-use type, Manning's ' $n$ ' value was provided as input. The roughness parameters for river channel were $\mathrm{n}=0.040$. Similarly, $\mathrm{n}=0.030$ and 0.035 for sandy and cultivated land respectively (Chow, 1959). Flood flows were also input as steady flow data in this window for various probability periods and reaching boundary conditions. The steady flow analysis window was then used to compute water surface profiles. A water depth raster file was created after the simulation and categorized into different water depth levels in the GIS environment. Figure 2 depicts the overall flood risk assessment procedure. 


\section{Flood frequency analysis}

The area of the basin below $3000 \mathrm{~m}$ above sea level is the most significant independent variable in the WECS/DHM approach. For unmeasured watersheds flooding of any river located in a catchment area (A) $\mathrm{km}^{2}$ below $3000 \mathrm{~m}$ above sea level, the WECS/ DHM approach appears suitable in most flood study instances (Gautam and Kharbujha 2006; Dangol, 2014). The flow, which is based on WECS and DHM's 2-year and 100year flood equations, is as follows:

$$
\mathrm{Q}_{2}=2.29\left(\mathrm{~A}<3_{\mathrm{k}}\right) 0.86
$$

$$
\mathrm{Q} 100=20.7\left(\mathrm{~A}<3_{\mathrm{k}}\right) 0.72
$$

Where Q denotes the flood flow in $\mathrm{m}^{3} / \mathrm{sec}$ and A denotes the basin area in $\mathrm{km}^{2}$. Floods in 2 years and 100 years are represented by the subscripts 2 and 100, respectively.

Similarly, the subscript $3 \mathrm{k}$ denotes a location that is less than 3000 meters above sea level. Floods in another return period are estimated using the following relationship (WECS, 1990).

$$
\mathrm{Q}_{\mathrm{f}}=\exp (\ln \mathrm{Q} 2+\mathrm{s} \sigma 1)
$$

Where $\sigma 1=\operatorname{In}(\mathrm{Q} 100 / \mathrm{Q} 2) / 2.326$ and $\mathrm{s}$ is the standard normal variable.

\section{Flood hazard assessment}

The flood risk estimation was made based on the flood depth given by the catchment's flood map. To do this, hazard levels were graded in terms of water depth, with these levels calculated by reclassifying the grid cells' flood depth boundaries. It was divided into four risk levels based on water depth: low (0-1 m), medium-low (1-2 m), medium $(2-3 \mathrm{~m})$, and high $(>3 \mathrm{~m})$ areas encircled by each level.

\section{Vulnerability assessment}

Flood vulnerability is determined by the land use characteristics and possible damage in the affected area. Because of the floodplain, land use themes can be carved with floodplain polygons for each simulated flood. Vulnerability maps were created for the vulnerability assessment. For those land use zones that are affected by each flood, common susceptible areas have been identified. According to Khanal et al. (2007) further land use vulnerability was categorized. The hazard level and general vulnerability are combined to create the risk level scale. 


\section{Risk assessment}

For risk evaluation, a risk matrix was employed. A flood risk analysis is done by combining the results of both vulnerability and hazard analysis, which are both related to the land use vulnerability class and flood depth risk class in a specific location. To construct a flood risk map, a land-use map was superimposed on the flood depth grid. Furthermore, the hazard analysis flood depth polygons intersect the land use vulnerability polygons. Scaling was done using subjective judgment. Shrestha et al., (2008) provided a risk assessment approach that was utilized to study the risk areas. There are four categories of risk and vulnerabilities: medium, moderately low, low, and very low. The resulting risk level scale had 16 cells and these cells were divided into five categories: extremely high, high, medium, moderately low, and low risk levels. The results of both the vulnerability and hazard assessments are included in the flood risk analysis.

\section{Results and discussion}

\section{Hydrological results}

The peak discharge of 2, 10, 50, 100, and the 1000 years return period of Andheri Khola using WECS/DHM method results are shown in Table 1. As the return period increases, the volume of discharge was also increased, which is similar to a natural phenomenon in general.

Table 1: Maximum peak discharge using WECS/DHM method

\begin{tabular}{|l|c|c|c|c|c|}
\hline Return Period (year) & 2 & 10 & 50 & 100 & 1000 \\
\hline Discharge $(\mathrm{m} 3 / \mathrm{s})$ & 27.2 & 66.23 & 113.2 & 136.73 & 416.98 \\
\hline
\end{tabular}

There is a power trend relationship between return period and peak discharge value having more than $99 \%$ coefficient of determination value. It revealed that there is no simple linear relation between the return period and peak discharge (Figure 3). Peak discharge increases very fast at the initial return period and the rate of change decreases as the return period increases. 


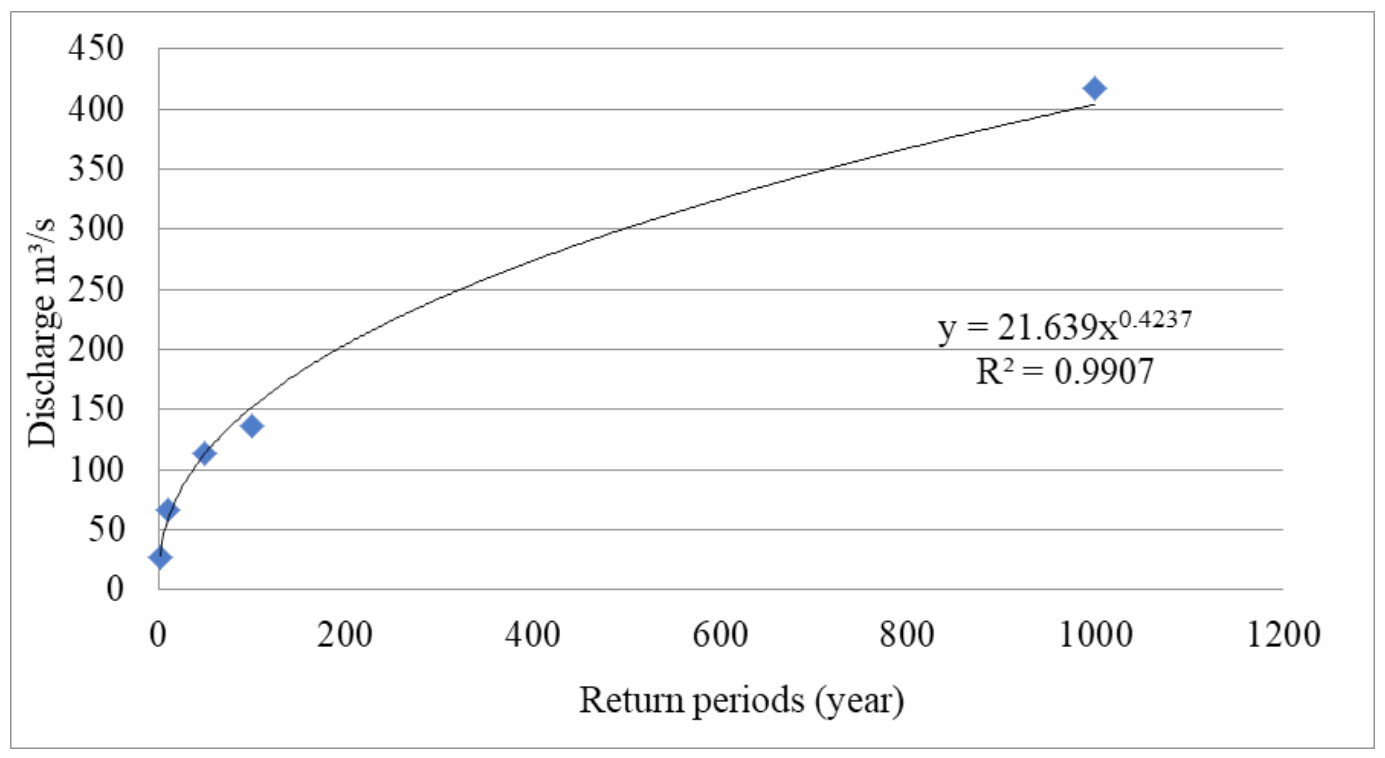

Figure 3: Relation of return period and peak discharge derived by WECS/DHM method

\section{Flood hazard analysis}

Figure 4 shows that high and moderate flood hazard area is increasing as the return period increases. In 2 years return period, the high flood hazard area is in the small parts of the central portion of the drainage channel. The moderate hazard zone is in the center as compared to the north and the south.

A higher proportion of the channel areas have been estimated low hazard level in the two-year return period. The high hazard zone has increased with moderate hazard zone in 50 years return period compared to two years. In 100 years return period, high and moderate hazard areas are highly increasing as compared to 50 years return period. Finally, the 1000 years return period flood hazard areas are far more than other estimations of the lower return periods. 

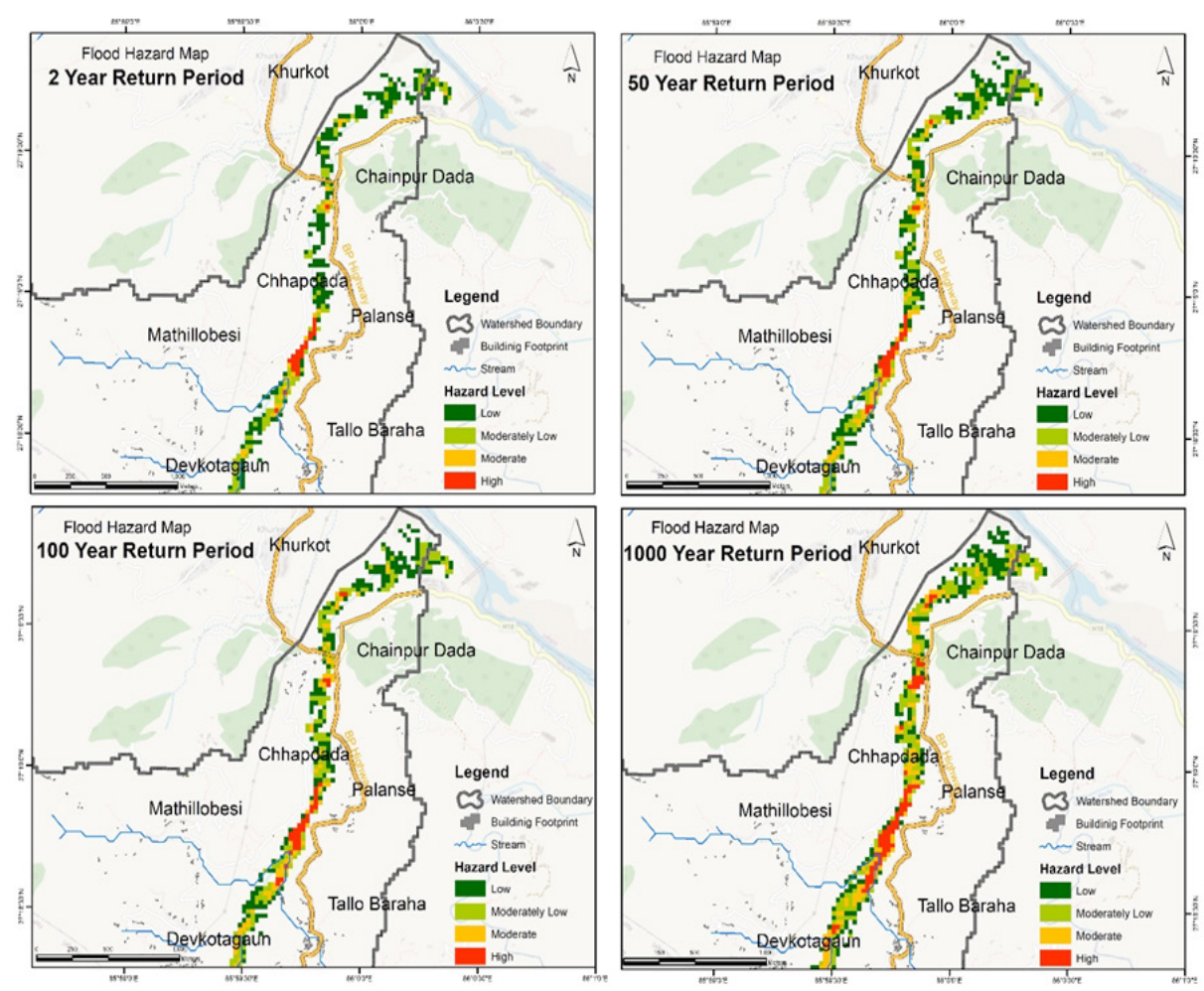

Figure 4: Flood hazard map of Andheri Khola in different return periods

A maximum of 35.03 ha, 41.86 ha, 42.68 ha, and 49.72 ha area could be inundated by 2-year, 50-year, 100-year, and 1000-year respectively. A maximum of 22.76 percentage area could be inundated in the 1000-year flood return period (Table 2). The estimated total area of inundation is increasing as the return period increases. Area proportions of low to high flood estimated areas are decreasing but high flood hazard area was estimated increasing as compared to moderate hazard area percentage in two and thousand years return period.

The trend of area percentage from high to low flood hazard area is decreasing with the increasing return period. There were nearly $34 \%$ area differences in low to high hazard area in two year return period, and it was nearly $24 \%$ in 50 years return period. Ultimately, the gaping of the area percentage is only 1.5 in the 1000 years return period, which is nearly 21 percent low in 100 years return period. 
Buddhi Raj Shrestha, Liladhar Sapkota, Chhabi Lal Chidi Flood risk... Vol. 15: 103-118, 2022

Table 2: Flood area in different return periods according to flood hazard level

\begin{tabular}{|l|c|c|c|c|c|c|c|c|}
\hline \multirow{2}{*}{ Hazard level } & \multicolumn{2}{|c|}{2 Year Flood } & \multicolumn{2}{c|}{50 Year Flood } & \multicolumn{2}{c|}{100 Year Flood } & \multicolumn{2}{c|}{$\begin{array}{c}\text { the } 1000 \text { Year } \\
\text { Flood }\end{array}$} \\
\cline { 2 - 10 } & Area & $\%$ & Area & $\%$ & Area & $\%$ & Area & $\%$ \\
\hline Low & 16.6 & 47.5 & 16.0 & 38.2 & 15.3 & 35.8 & 12.1 & 24.3 \\
\hline Moderately Low & 10.0 & 28.6 & 13.1 & 31.2 & 13.5 & 31.6 & 15.4 & 31.1 \\
\hline Moderate & 3.6 & 10.3 & 6.8 & 16.2 & 7.6 & 17.7 & 10.9 & 21.9 \\
\hline High & 4.8 & 13.7 & 6.0 & 14.4 & 6.4 & 15.0 & 11.3 & 22.8 \\
\hline Total & 35.0 & 100 & 41.9 & 100 & 42.7 & 100 & 49.7 & 100 \\
\hline
\end{tabular}

Figure 5 shows that the changing trends of the area of different hazard levels with increasing return periods. The low hazard area is highly decreasing with increasing return period, which is nearly $48 \%$ in 2 year return period to $24.3 \%$ in the 1000 years return period. Area of other hazard levels is increasing replaced to lower hazard levels, in which higher proportion is replaced to low hazard level. The highest increase is in moderate hazard level (11.62\%) from 2 to the 1000 years return period followed by high hazard level $(9.1 \%)$. The moderate level has the lowest rate of increase in area.

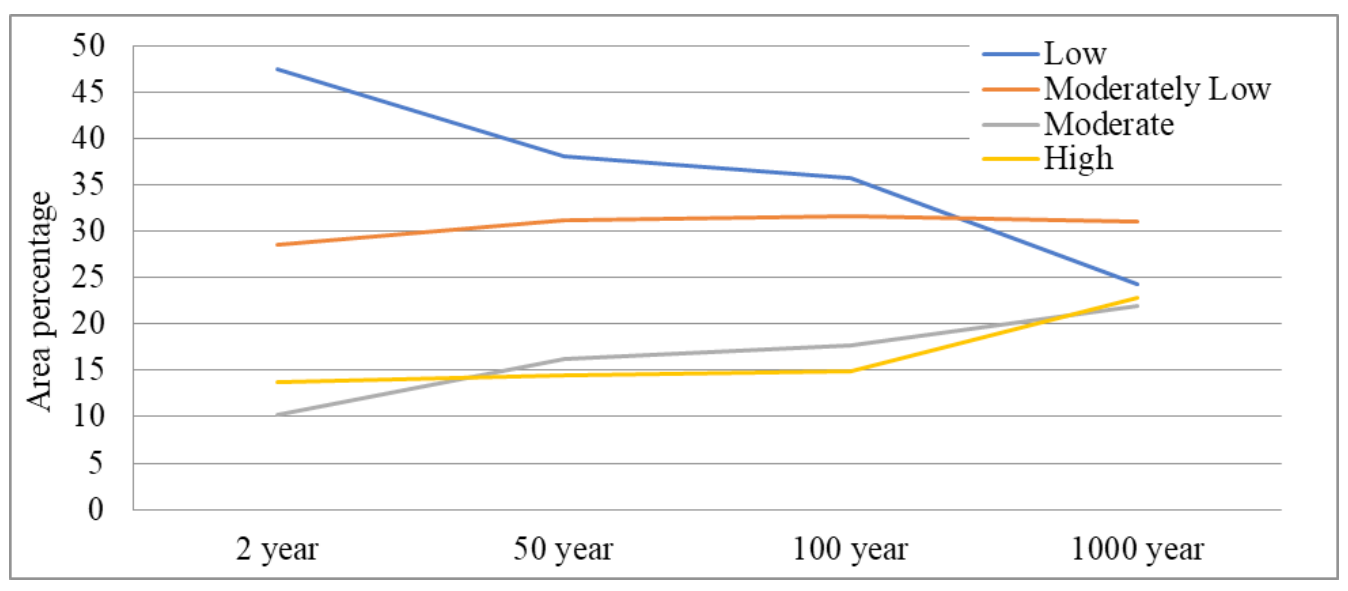

Figure 5: Trend of area change of different hazard levels in return period

Figure 6 shows the 3 dimensional perspective views of the flood plain at the adjoining parts of Andheri Khola and Sunkoshi River, which is the most critical part of the study area. Flood hazard level in the 1000 years returns period has shown on transparent blue color on Google Earth image. The model shows that the eastern part of the Khurkot settlement is at high risk. Andheri Khola Bridge and surrounding parts could be inundated in the 1000 years return period flood. The building and other infrastructures 
construction near to this area could be high risk in future. Large parts of cultivated land including with proposed new city areas of Khurkot are also at a high risk of flood, which revealed that urban planning, infrastructure development, and other land-use planning should be carefully taken into consideration for a safe sustainable and secure future. This is an example of the risk of flood hazards.

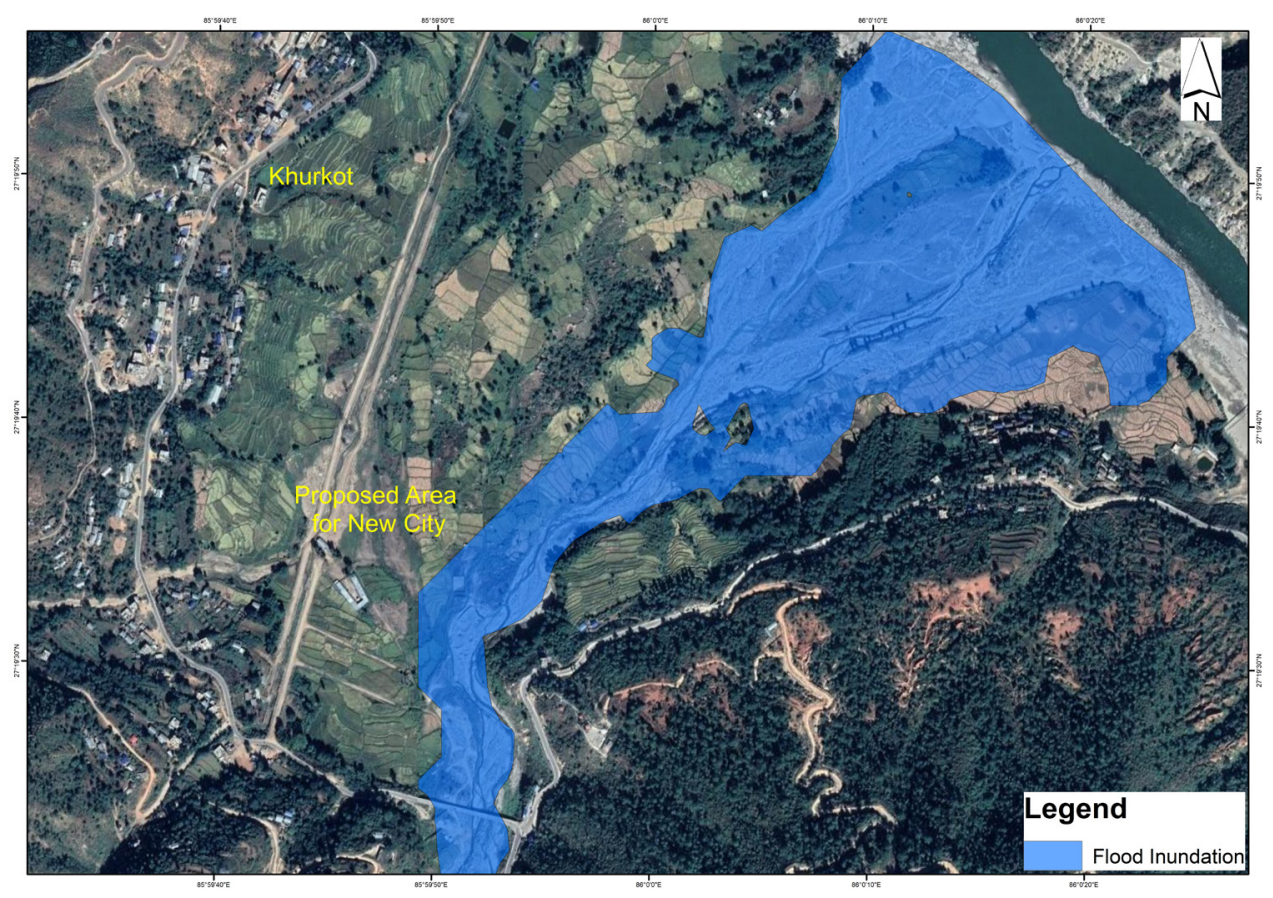

Figure 6: Flood scenario of the 1000 years return period near Khurkot

\section{Flood vulnerability analysis}

The assessment of the flood areas indicated that a large proportion (average $78.32 \%$ ) of the vulnerable area lies in the sand area followed by cultivation land, bush and forest area comprising an average of $16.95 \%, 2.90 \%$, and $1.84 \%$ respectively (Table 3 ). It is because the sand area is along the river channel; cultivated lands are outside the sandy area. Accordingly, shrubs and forest land are far mostly in the steep slopes of river terraces and foothill areas. Thus, the sandy area is at the highest risk zone followed by cultivated land. 
Buddhi Raj Shrestha, Liladhar Sapkota, Chhabi Lal Chidi Flood risk... Vol. 15: 103-118, 2022

Table 3: Vulnerability level by land use category flood risk analysis

\begin{tabular}{|l|c|c|c|c|c|c|c|c|}
\hline \multirow{2}{*}{ Land use } & \multicolumn{2}{|c|}{2 Year Flood } & \multicolumn{3}{c|}{50 Year Flood } & \multicolumn{2}{c|}{ 100 Year Flood } & \multicolumn{2}{|c|}{$\begin{array}{c}\text { the 1000 Year } \\
\text { Flood }\end{array}$} \\
\cline { 2 - 11 } & Area (h) & $\%$ & Area (h) & $\%$ & Area (h) & $\%$ & Area (h) & $\%$ \\
\hline Forest & 0.73 & 2.08 & 0.78 & 1.85 & 0.78 & 1.83 & 0.79 & 1.59 \\
\hline Bush & 1.14 & 3.26 & 1.14 & 2.73 & 1.19 & 2.78 & 1.4 & 2.81 \\
\hline Cultivation & 5.07 & 14.46 & 7.05 & 16.84 & 7.25 & 16.99 & 9.69 & 19.49 \\
\hline Sand & 28.1 & 80.2 & 32.89 & 78.57 & 33.46 & 78.4 & 37.84 & 76.11 \\
\hline Total & 35.03 & 100 & 41.86 & 100 & 42.68 & 100 & 49.72 & 100 \\
\hline
\end{tabular}

Figure 7 shows that the highest percentage of vulnerable area change is in the cultivated land because most of the area is under cultivation just outside of the sand area. Thus, it has the highest effect if the inundation area increases. It revealed that increased flood inundation area is mostly in the cultivated land. The highest percentage increase from 2 to 50 years returns period, which is followed by 100 to the 1000 years. Bush area has decreased from 50 to 100 years and 100 to 1000 years.

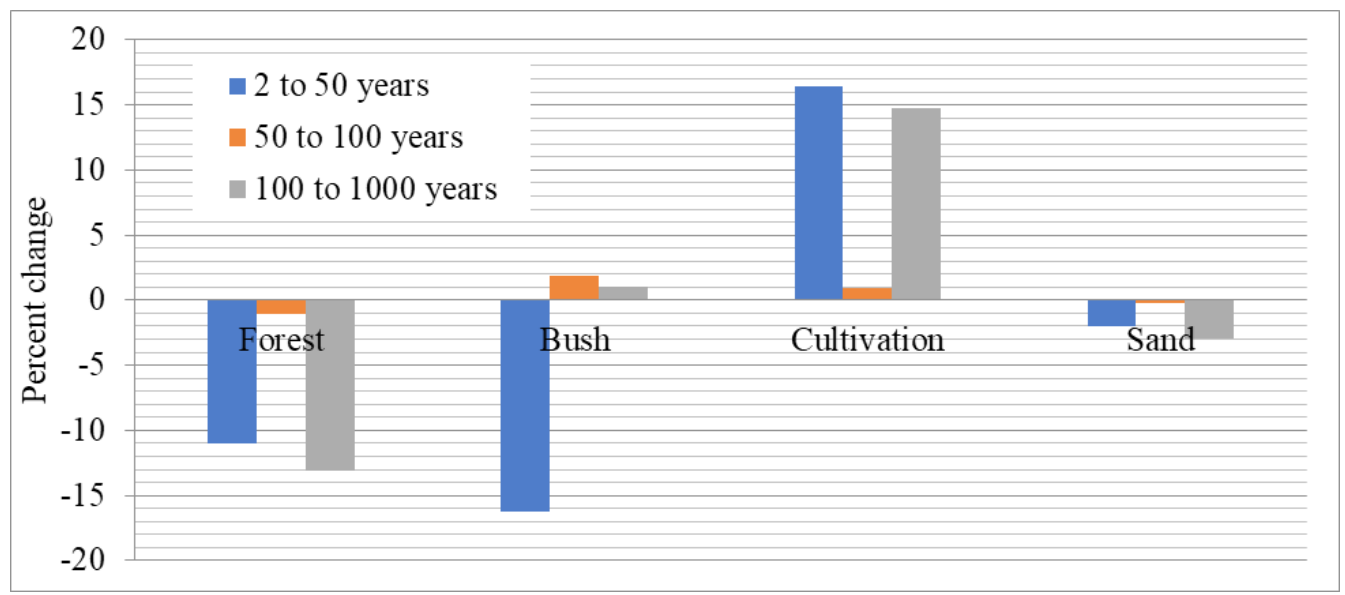

Figure 7: Change percentage of vulnerable land uses by returning period

\section{Flood risk assessment}

The study revealed that most of the areas are covered by low and moderate risk levels (Table 4). There are bush, forest, and sand areas in the low and moderately low-risk zone. Cultivated land is in the moderate risk zone. The result demonstrated that the highest percentage of cultivation land (10.86\%) area is at risk by the 1000 -year return period flood. 
Table 4: Land use risk in different flood return periods

\begin{tabular}{|c|c|c|c|c|c|c|c|c|c|}
\hline \multirow[t]{2}{*}{ Risk level } & \multirow[t]{2}{*}{$\begin{array}{l}\text { Land use } \\
\text { category }\end{array}$} & \multicolumn{2}{|c|}{ 2-year flood } & \multicolumn{2}{|c|}{ 50-year flood } & \multicolumn{2}{|c|}{ 100-year flood } & \multicolumn{2}{|c|}{$\begin{array}{l}\text { the } 1000 \text {-year } \\
\text { flood }\end{array}$} \\
\hline & & Area & $\%$ & Area & $\%$ & Area & $\%$ & Area & $\%$ \\
\hline \multirow[t]{4}{*}{ Low } & Forest & 0.73 & 2.08 & 0.78 & 1.85 & 0.78 & 1.83 & 0.79 & 1.59 \\
\hline & Bush & 1.14 & 3.26 & 1.14 & 2.73 & 1.19 & 2.78 & 1.40 & 2.81 \\
\hline & Cultivation & 2.90 & 8.28 & 3.86 & 9.22 & 3.92 & 9.19 & 4.29 & 8.63 \\
\hline & Sand & 28.10 & 80.2 & 32.89 & 78.57 & 33.46 & 78.40 & 37.84 & 76.11 \\
\hline Moderate & Cultivation & 2.17 & 6.18 & 3.19 & 7.63 & 3.33 & 7.79 & 5.40 & 10.86 \\
\hline \multicolumn{2}{|l|}{ Total } & 35.03 & 100 & 41.86 & 100 & 42.68 & 100 & 49.72 & 100 \\
\hline
\end{tabular}

It has already been defined about the second larger part of the area of risk is under cultivation, which is more vulnerable because the sandy area is a naturally flooded area at present. Thus, cultivated land is the major concern of risk of flood in the study area. A higher proportion of the cultivated area was under a low flood risk zone compared to moderate risk area in 2 years return period. The areas of both low and moderate risk zone of cultivated are in similar proportion in 50 years and 100 years return period, although the area of the low-risk zone is quite higher compared to moderate one. In the 1000 years return period, both moderate and low-risk areas have increased compared to the shorter return period. Inverse to another return period, moderate risk area has outnumbered to low-risk area, which indicates that future flood risk in the study area is mostly in cultivated land (Figure 8).

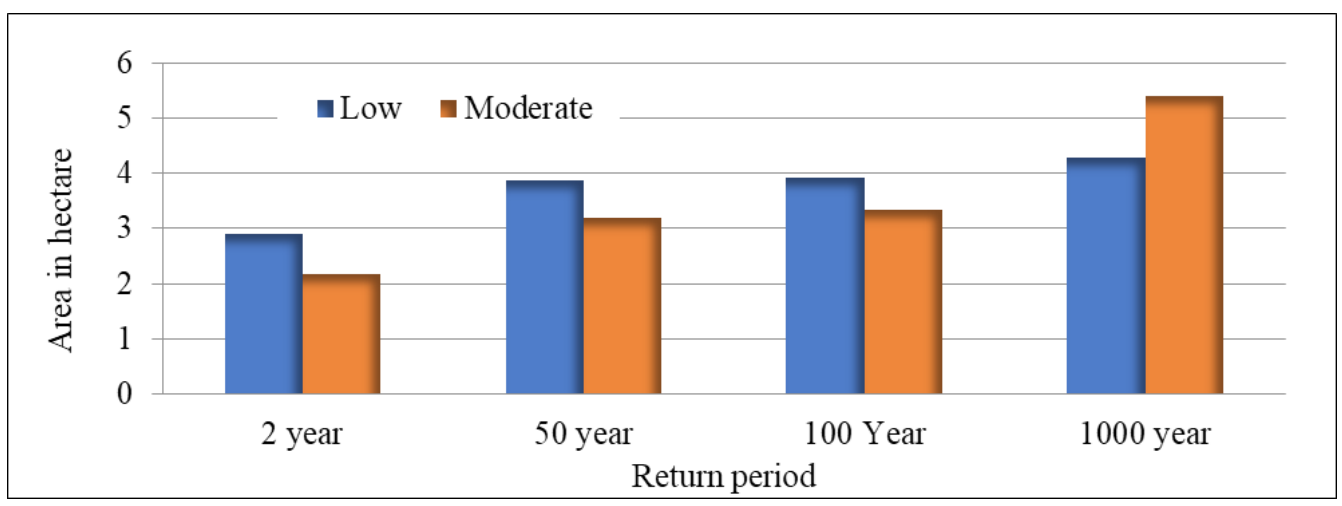

Figure 8: Area of the risk level of cultivated land in different return periods

\section{Conclusion}

Andheri Khola's flood frequency, flood risk, and vulnerability were all evaluated. The maximum water discharge was calculated using the WECS/DHM approach. The return periods of 2, 50,100, and 1000 years inundate a maximum of 49.72 hectares. 
The majority of the regions that are flooded have water depths greater than 3 meters, according to the floodwater depth analysis. More than $70 \%$ of the sandy area is in a flood-prone area. Near the Andheri Khola, the study area's agriculture land is under jeopardy. From two years until the 1000th return period, water discharge rose from 27.3 to roughly $427 \mathrm{~m}^{3} / \mathrm{second}$. Water discharge is dependent on return periods due to the power function. Low flood hazard zones are shrinking as the return time lengthens, while moderate, high, and very high hazard areas are growing. As a result, the lowrisk zone has been replaced with higher-risk zones with a longer return period. Sandcovered areas are the most vulnerable to flooding, followed by cultivated land. The sand area is already at the risk of flooding, but so is a big portion of the cultivated land. Bush, woodland, and sand areas have low risk levels, whereas the cultivated land has both low and moderate risk levels, according to risk assessments. In the 1000 return period, the area of cultivated land with a moderate risk level has expanded more than the area of cultivated land with a low risk level. The flood-prone area includes not just cultivated land, but also the settlements and roadways. As a result, all planning and building activities along the stream corridor should take flood risk into consideration.

\section{References}

Aryal, D., Wang, L., Adhikari, T. R., Zhou, J., Li, X., Shrestha, M. and Chen, D. (2020). A model-based flood hazard mapping on the southern slope of Himalaya. Water, 12(2):540. https://doi.org/10.3390/w12020540

Awal, R. (2007). Floodplain analysis and risk assessment of Lakhandei River. Innovative Initiatives in Disaster Risk Reduction, 119-128.

Banstola, P., Krishna, P. and Sapkota, B., (2019) Flood Risk Mapping and Analysis Using Hydrodynamic Model HEC-RAS: A Case Study of Daraudi River, Chhepatar, Gorkha, Nepal. Journal of Natural Resources, 2(3), 25-44. https:// doi.10.33002/nr2581.6853.02033

Bhattarai, P., Khanal, P., Tiwari, P., Lamichhane, N., Dhakal, P., Lamichhane, P., and Dahal, P. (2019). Flood Inundation Mapping of Babai Basin using HEC-RAS and GIS. Journal of the Institute of Engineering, 15(2), 32-44. https://doi. org/10.3126/jie.v15i2.27639

Brooks, N. (2003). Vulnerability, risk, and adaptation: A conceptual framework. Tyndall Centre for climate change research working paper, 38(38), 1-16.

Brunner, G. W (2016). HEC-RAS River Analysis System Modeling User's Manual US Army Corps of Engineers Hydrologic Engineering Center. Information on http://www. hec. usace. army. mil.

Chow, V.T. (1959). Open Channel Hydraulics. McGraw Hill Inc., Singapore 
Dangol, S. (2014). Use of Geo-Informatics in flood hazard mapping: A case of Balkhu River. Nepalese Journal of Geoinformatics, 13, 52-57. https://doi.org/10.3126/ njg.v13i0.16937

Dahal, K., and Timalsina, K. P. (2017). New towns development: A wave of the future planning practices in Nepal. Tribhuvan University Journal, 31(1-2), 139-152. https://doi.org/10.3126/tuj.v31i1-2.25346

Dhital, M. R., Shrestha, R., Shrestha, G. B., and Tripathi, D. (2005). Hydrological hazard mapping in Rupandehi district, West Nepal. Journal of Nepal Geological Society, 31, 59-66. https://doi.org/10.3126/jngs.v31i0.261

Dhungana, H., Pain, A., and Dhungana, S. P. (2016). Disaster risk management and meso-level institutions in Nepal: a case study of floods in Tinau River in Western Terai. Climate Change and Rural Institutions (CCRI) Research Project, CCRI Case Study, 6.

DWIDP.(2013). Disaster Review. Kathmandu: Department of Water Induced Disaster Prevention

Dilley, M., Chen, R. S., Deichmann, U., Lerner-Lam, A. L., and Arnold, M. (2005). Natural Disaster hotspots: a global risk analysis. International Bank for Reconstruction and Development /The World Bank and Columbia University, Washington, DC

El-Naqa, A., and Jaber, M. (2018). Floodplain analysis using ArcGIS, HEC-GeoRAS, and HEC-RAS in Attarat Um Al-Ghudran oil shale concession area, Jordan. $J$. Civil Environ Eng, 8(5), 1-11. https://doi. 10.4172/2165-784X.1000323

Gautam, D. K., and Kharbuja, R. G. (2006). Flood hazard mapping of Bagmati River in Kathmandu valley using geo-informatics tools. Journal of hydrology and meteorology, 3(1): 1-9.

Horritt, M. S., and Bates, P. D. (2002). Evaluation of 1D and 2D numerical models for predicting river flood inundation. Journal of hydrology, 268(1-4), 87-99. https://doi.org/10.1016/S0022-1694(02)00121-X

Huțanu, E., Mihu-Pintilie, A., Urzica, A., Paveluc, L. E., Stoleriu, C. C., and Grozavu, A. (2020). Using 1D HEC-RAS Modeling and LiDAR Data to Improve Flood Hazard Maps Accuracy: A Case Study from Jijia Floodplain (NE Romania). Water, 12(6), 1624. https://doi.org/10.3390/w12061624

Karki, S., Koirala, M., Pradhan, A. M. S., Thapa, S., Shrestha, A., and Bhattarai, M (2011). GIS-based flood hazard mapping and vulnerability to climate change assessment: A Case Study from Kankai Watershed, Eastern Nepal. Lalitpur: Nepal Climate Change Knowledge Management Center, Nepal Academy of Science and Technology.

Khanal, N. R., Shrestha, M., and Ghimire, M. (2007). Preparing for flood disaster: mapping and assessing hazard in the Ratu Watershed, Nepal. Kathmandu: International Centre for Integrated Mountain Development (ICIMOD). 
Liu, Z., Merwade, V., and Jafarzadegan, K. (2019). Investigating the role of model structure and surface roughness in generating flood inundation extents using one $\square$ and two $\square$ dimensional hydraulic models. Journal of Flood Risk Management, 12(1), e12347. https://doi.org/10.1111/jfr3.12347

Mool, P. K., Maskey, P. R., Koirala, A., Joshi, S. P., Lizong, W., Shrestha, A. B., and Shrestha, R. B. (2011). Glacial lakes and glacial lake outburst floods in Nepal (No. 98829, pp. 1-109). The World Bank.

MoHA and DPNeT. 2013. Nepal disaster report, 2013. Kathmandu: Government of Nepal, Ministry of Home Affairs.

NSET. (2016). Disasters in Nepal: Inventory of events and analysis of impacts (Period covered 1971-2016), Preliminary Analysis (In-house unpublished report under the DesInventar Project of NSET). Kathmandu: National Society for Earthquake Technology Nepal.

Shrestha, A. B., Shah, S. H., and Karim, R. (2008). Resource manual on flash flood risk management. Kathmandu: Internet Centre for Integrated Mountain Development, ICIMOD

Shrestha, B. R., Rai, R. K., and Marasini, S. (2020). Review of Flood Hazards Studies in Nepal. The Geographic Base, 7, 24-32. https://doi.org/10.3126/tgb.v7i0.34266

Shrestha, M. S., Heggen, R., Thapa, K., Ghimire, M., and Shakya, N. (2004). Flood risk and vulnerability mapping using GIS: a Nepal case study. In Proceeding of the second Asia Pacific Association of Hydrology and Water Resources Conference, Singapore (Vol. 1, pp. 180-190).

Tamang, N. B., and Tamrakar, N. K. (2017). Use of GIS and HEC-RAS tools in the flood hazard mapping of an ungauged river: A case study of the Malekhu Khola, central. International Journal Of Advanced Research in Engineering and Management, 57-64.

Sharma, T. P. P., Zhang, J., Koju, U. A., Zhang, S., Bai, Y., \& Suwal, M. K. (2019). Review of flood disaster studies in Nepal: A remote sensing perspective. International journal of disaster risk reduction, 34, 18-27.

Thapa, S., Shrestha, A., Lamichhane, S., Adhikari, R., and Gautam, D. (2020). Catchment-scale flood hazard mapping and flood vulnerability analysis of residential buildings: The case of Khando River in eastern Nepal. Journal of Hydrology: Regional Studies, 1-12. https://doi.org/10.1016/j.ejrh.2020.100704

WECS (1990). Methodology for estimating hydrological characteristics of ungauged locations in Nepal, His majesty's Government of Nepal, Ministry of Water Resources Water and Energy Commission Secretariat and Department of Hydrology and Meteorology, Kathmandu, Nepal, July 1990. 